Journal of Epidemiology and Public Health (2019), 4(4): 328-337

https://doi.org/10.26911/jepublichealth.2019.04.04.08

\title{
Contextual Effect of School on the Risk Obesity among High School Students in Surakarta, Central Java: A Multilevel Analysis Evidence
}

\author{
Rita Setiyaningsih'), Yulia Lanti Retno Dewi²), Rita Benya Adriani3) \\ 1)Masters Program in Public Health, Universitas Sebelas Maret \\ 2)Faculty of Medicine, Universitas Sebelas Maret \\ 3)Diploma Program in Speech Therapy, School of Health Politechnics Surakarta
}

\begin{abstract}
Background: Obesity is a public health problem in various countries, one of which is Indonesia. The impact of obesity in adulthood is high blood pressure and high cholesterol which can later trigger cardiovascular disease. This study aimed to examine contextual effect of school on the risk obesity among high school students in Surakarta.

Subjects and Method: This was an observational analytic study with a case control approach. The study was conducted in April 2019. The sample was selected by stratified random sampling of 225 students in 15 schools in Surakarta with a case and control group. The dependent variable was obesity. The independent variables were parental salary, parental knowledge, pocket money, school food environment, food intake, physical activity, maternal BMI, paternal BMI. Data collection techniques used questionnaires and analyzed by multilevel logistic regression in Stata 13.

Results: Obesity in adolescents was directly and significantly affected by parental income $\geq \mathrm{Rp}$ $1,800,000(\mathrm{OR}=4.53 ; 95 \% \mathrm{CI}=1.80$ to $11.36 ; \mathrm{p}=0.001)$, high parental knowledge $(\mathrm{OR}=0.36 ; 95 \%$ $\mathrm{CI}=0.15$ to $0.91 ; \mathrm{p}=0.030)$, allowance $\geq \mathrm{Rp} 10,000(\mathrm{OR}=3.80 ; 95 \% \mathrm{CI}=1.63$ to $8.86 ; \mathrm{p}=0.002)$, food intake $\geq$ recommended dietary allowances $(\mathrm{OR}=3.62 ; 95 \% \mathrm{CI}=1.43$ to $9.19 ; \mathrm{p}=0.007)$, high physical activity $(\mathrm{OR}=0.06 ; 95 \% \mathrm{CI}=0.02$ to $0.18 ; \mathrm{p}<0.001)$, maternal $\mathrm{BMI}>27 \mathrm{~kg} / \mathrm{m}^{2}(\mathrm{OR}=7.08$; $95 \% \mathrm{CI}=2.39$ to $20.99 ; \mathrm{p}<0.001)$, and paternal $\mathrm{BMI}>27 \mathrm{~kg} / \mathrm{m}^{2}(\mathrm{OR}=2.63 ; 95 \% \mathrm{CI}=1.10$ to 20.96; $\mathrm{p}=0.031$ ). School had a contextual effect on obesity with intra-class correlation $($ ICC $)=16.99 \%$.

Conclusion: Obesity in adolescents is directly and significantly affected by parental income $\geq \mathrm{Rp}$ 1,800,000, high parental knowledge, allowance $\geq \mathrm{Rp} 10,000$, high physical activity, maternal BMI $>27 \mathrm{~kg} / \mathrm{m}^{2}$, and paternal BMI $>27 \mathrm{~kg} / \mathrm{m}^{2}$. School has contextual effect on obesity.
\end{abstract}

Keywords: obesity, adolescents, multilevel analysis

\section{Correspondence:}

Rita Setiyaningsih. Masters Program in Public Health, Universitas Sebelas Maret, Jl. Ir. Sutami No. 36 A, Surakarta, Central Java. Email: ritasetiya2608@gmail.com. Mobile: +6282220489153

\section{BACKGROUND}

According to the World Health Organization (WHO) (2018) in 2016, more than 340 million children and adolescents aged 5-19 years were overweight and obese. Obesity has become a public health problem in various countries, one of which is Indonesia. Data on 2007-2013 reports that Indonesia has a prevalence of overweight and obesity in adolescents aged 13-15 years at $10.8 \%$, consisting of $8.3 \%$ overweight and $2.5 \%$ obesity, while adolescents aged $16-18$ years have a prevalence of overweight and obesity of $7.3 \%$ consisting of $5.7 \%$ overweight and 1.6\% obesity (Basic Health Center, 2013). Excessive nutrition which results in obesity can occur at the age of children to adults. Energy intake stored in the body can be reduced if adolescent do a lot of physical activity. Physical activity can affect the health of adolescents, because obese adolescents have lower physical activity compared to adolescents who are not obese (Pramono and Sulchan, 2014). Besides 
obesity is associated with physical activity, it is often also associated with genetic factors, such as body mass index (BMI) of the father and mother (Ornellas et al., 2017).

The impacts caused by obesity include high blood pressure and high cholesterol which can later trigger cardiovascular disease. Cardiovascular disease is not a compromise in the early years of obesity, but in the years to come. Obesity can be triggered by various factors such as parental income, parental knowledge, pocket money, school food environment, food intake, physical activity, paternal BMI and maternal BMI (Kelsey et al., 2014).

Based on some of these statements the researcher wants to know and analyze the Multilevel Determinant of Obesity in Adolescent Senior High School Students in Surakarta.

\section{SUBJECTS AND METHOD}

\section{Study Design}

This was an analytic observational study with a case control design. The study was conducted at 15 schools in Surakarta, Central Java, Indonesia, on April 2019.

\section{Population and Sample}

The source population was divided into two namely adolescents who were obese and adolescents who were not obese. A sample of 225 adolescents was selected by stratified random sampling.

\section{Study Variables}

The dependent variable was obesity. The independent variables at level 1 were parental salary, parental knowledge, pocket money, food intake, physical activity, maternal BMI, and paternal BMI and school level at level 2.

4. Operational Definition of Variables Obesity was an individual's condition which was assessed from the accumulation of excess fat in the body, measured by the scales and stature meters.

Parental income was the basic income in the form of income per month, which was obtained from the work of a father or mother, and or both measured in rupiah.

Parental knowledge was knowledge about obesity that is known by parents, including the definition of obesity, the causes and effects of obesity, measured by a questionnaire.

Pocket money was the amount of money received by subjects of the study in one day, consisting of pocket money from parents or family, measured in rupiah.

School food environment was an environment where adolescent buy snacks, in the form of food and drinks, which are inside the building or outside the school building, measured by a questionnaire.

Physical activity was an activity or physical activity carried out by subjects of the study within a period of 7 days, assessed based on the frequency of physical activity undertaken, measured by a questionnaire.

Food intake was food consumed by adolescent every day, which started from breakfast to dinner before going to bed, measured by questionnaires.

Paternal BMI was a method used to monitor the nutritional status of adults, related to underweight and overweight due to excessive fat accumulation, measured by scales and stature meters.

Maternal BMI was a method used to monitor the nutritional status of adults, related to underweight and overweight due to excessive fat accumulation, measured by scales and stature meters.

\section{Data Analysis}

Univariate analysis was used to see the frequency distribution and percentage characteristics of the subjects of the study. Bivariate analysis was used to study the association between obesity with independent 
Journal of Epidemiology and Public Health (2019), 4(4): 328-337

https://doi.org/10.26911/jepublichealth.2019.04.04.08

variables using the chi-square test. Multivariate analysis used logistic regression through a multilevel approach.

\section{Research Ethics}

Research ethics includes research approval (informed consent), anonymity, confidentiality, and ethical approval. Ethical clearance was obtained from Research Ethics Committee of the Faculty of Medicine, Uni-

Table 1. Sample Characteristics

Parental Income
Low $(<\mathrm{Rp} 1,800,000)$
High $(\geq \mathrm{Rp}$ 1,800,000)
Parental Knowledge
Low
High
Pocket money
Low $(<\mathrm{Rp}$. 10000)
High $(\geq \mathrm{Rp}$. 10000)
Food intake
$<$ Recommended Dietary Allow
$\geq$ Recommended Dietary Allo
Physical Activity
Low
High
Maternal BMI
Normal weight $\left(17-23 \mathrm{~kg} / \mathrm{m}^{2}\right)$
Obese $\left(>27 \mathrm{~kg} / \mathrm{m}^{2}\right)$
Paternal BMI
Normal weight $\left(18-25 \mathrm{~kg} / \mathrm{m}^{2}\right)$
Obese $\left(>27 \mathrm{~kg} / \mathrm{m}^{2}\right)$
Obesity
Normal weight
Obese$$
\text { Variable }
$$

\section{Parental Income}

High ( $\geq \operatorname{Rp~1,800,000)}$

Parental Knowledge

Low

Pocket money

Low (< Rp. 10000)

High ( $\geq$ Rp. 10000)

$<$ Recommended Dietary Allowance

$\geq$ Recommended Dietary Allowance

Physical Activity

Low

Maternal BMI

Normal weight $\left(17-23 \mathrm{~kg} / \mathrm{m}^{2}\right)$

Normal weight $\left(18-25 \mathrm{~kg} / \mathrm{m}^{2}\right)$

Obese $\left(>27 \mathrm{~kg} / \mathrm{m}^{2}\right)$

Normal weight

The frequency distribution of the characteristics of the study subjects is described in table 1 which shows that most of the parental income were 113 (50.2\%), most of the parental knowledge was 113 (50.2\%).

Characteristics of pocket money mostly with high pocket money that 113 (50.2\%), versitas Sebelas Maret, Surakarta with No. 81 / -UN27.06 / KEPK / 2019.

\section{RESULTS}

\section{Sample Characteristics}

A sample of 225 adolescents was divided into two groups, consisting of 75 obese adolescents (case) and 150 normal weight adolescents (control). Table 1 described sample characteristics (categorical data).

\section{Frequency (n) $\quad$ Percentage (\%)}

$\begin{array}{cc}112 & 49.8 \\ 113 & 50.2 \\ & \\ 112 & 49.8 \\ 113 & 50.2 \\ & \\ 112 & 49.8 \\ 113 & 50.2 \\ & \\ 100 & 44.4 \\ 125 & 55.6 \\ & \\ 96 & 42.7 \\ 129 & 57.3 \\ & \\ 107 & 47.6 \\ 118 & 52.4 \\ & \\ 134 & 59.6 \\ 91 & 40.4 \\ & \\ 150 & 66.7 \\ 75 & 33.3\end{array}$

the majority of adolescent food intake was $\geq$ nutritional needs that were 125 (55.6\%), physical activity characteristics were mostly with high physical activity that was 129 (57.3\%), most of the characteristics of maternal BMI were obese as many as 118 (52.4\%), the characteristics of paternal BMI were mostly obese as many as 134 (59.6\%). 
Table 2. Bivariate Analysis

\begin{tabular}{|c|c|c|c|c|c|c|c|c|}
\hline \multirow{3}{*}{ Independent Variable } & \multicolumn{4}{|c|}{ Obesity } & \multirow{3}{*}{$\mathbf{O R}$} & \multicolumn{2}{|c|}{$95 \% \mathrm{CI}$} & \multirow{3}{*}{$\mathbf{p}$} \\
\hline & \multicolumn{2}{|c|}{ Not obese } & \multicolumn{2}{|c|}{ Obese } & & \multirow{2}{*}{$\begin{array}{r}\text { Lower } \\
\text { Limit }\end{array}$} & \multirow{2}{*}{$\begin{array}{l}\text { Upper } \\
\text { Limit }\end{array}$} & \\
\hline & $\mathbf{n}$ & $\%$ & $\mathbf{n}$ & $\%$ & & & & \\
\hline \multicolumn{9}{|l|}{ Parental Income } \\
\hline Low $(<\operatorname{Rp} 1,800,000)$ & 93 & 83.0 & 19 & 17.0 & 4.80 & 2.60 & 8.90 & $<0.001$ \\
\hline High ( $\geq$ Rp 1,800,000) & 57 & 50.4 & 56 & 49.6 & & & & \\
\hline \multicolumn{9}{|l|}{ Parental Knowledge } \\
\hline Low & 67 & 59.8 & 45 & 40.2 & 0.54 & 0.31 & 0.95 & 0.030 \\
\hline High & 83 & 73.5 & 30 & 26.5 & & & & \\
\hline \multicolumn{9}{|l|}{ Pocket Money } \\
\hline Low $(<\operatorname{Rp} 10,000)$ & 86 & 76.8 & 26 & 23.2 & 2.53 & 1.43 & 4.50 & 0.001 \\
\hline $\operatorname{High}(\geq \operatorname{Rp} 10,000)$ & 64 & 56.6 & 49 & 43.4 & & & & \\
\hline \multicolumn{9}{|l|}{ Food intake } \\
\hline $\begin{array}{l}<\text { Recommended Dietary } \\
\text { Allowance (RDA) }\end{array}$ & 80 & 80.0 & 20 & 20.0 & 3.14 & 1.72 & $5 \cdot 75$ & $<0.001$ \\
\hline $\begin{array}{l}\geq \text { Recommended Dietary } \\
\text { Allowance (RDA) }\end{array}$ & 70 & 56.0 & 55 & 44.0 & & & & \\
\hline \multicolumn{9}{|l|}{ Physical Activity } \\
\hline Low & 44 & 45.8 & 52 & 54.2 & 0.18 & 0.10 & 0.34 & $<0.001$ \\
\hline High & 106 & 82.2 & 23 & 17.8 & & & & \\
\hline \multicolumn{9}{|l|}{ Maternal BMI } \\
\hline Not obese $\left(17-23 \mathrm{~kg} / \mathrm{m}^{2}\right)$ & 85 & 79.4 & 22 & 20.6 & 3.15 & 1.74 & $5 \cdot 70$ & $<0.001$ \\
\hline Obese $\left(>27 \mathrm{~kg} / \mathrm{m}^{2}\right)$ & 65 & 55.1 & 53 & 44.9 & & & & \\
\hline \multicolumn{9}{|l|}{ Paternal BMI } \\
\hline Not obese $\left(18-25 \mathrm{~kg} / \mathrm{m}^{2}\right)$ & 100 & 74.6 & 34 & 25.4 & 2.41 & 1.37 & 4.25 & 0.002 \\
\hline Obese $\left(>27 \mathrm{~kg} / \mathrm{m}^{2}\right)$ & 50 & 54.9 & 41 & 45.1 & & & & \\
\hline
\end{tabular}

\section{Analisis Bivariat}

Bivariate analysis was used to examine the association between independent variables (parental income, parental knowledge, pocket money, food intake, physical activity, maternal BMI, and paternal BMI) with the dependent variable (obesity). The complete bivariate analysis results can be seen in table 2. This shows that there was an association between parental income and obesity. Adolescent with high parental income, had a risk for obesity 4.80 times compared with low parental income $(\mathrm{OR}=$ $4.80 ; 95 \% \mathrm{CI}=2.60$ to $8.90 ; \mathrm{p}<0.001)$. There was an association between parental knowledge and obesity. Adolescent with high parental knowledge, had a risk of not being obese 0.54 times compared with low parental knowledge. $(\mathrm{OR}=0.54 ; 95 \% \mathrm{CI}=$ 0.31 to $0.95 ; \mathrm{p}=0.030$ ).
There was an association between pocket money and obesity. Adolescent with high pocket money, had a risk for obesity 2.53 times compared with a low allowance. $(\mathrm{OR}=2.53 ; 95 \% \mathrm{CI}=1.43$ to 4.50; $\mathrm{p}=0.001$ ). There was an association between food intake and obesity. Adolescents with food intake that $\geq$ Recommended Dietary Allowance (RDA), had a risk for obesity 3.14 times compared with food intake $<$ Recommended Dietary Allowance (RDA) $(\mathrm{OR}=3.14 ; 95 \% \mathrm{CI}=1.72$ to $5.75 ; \mathrm{p}<0.001)$. There was an association between physical activity and obesity. Adolescent with high physical activity, had a risk of not being obese 0.18 times compared with low physical activity $(\mathrm{OR}=0.18 ; 95 \% \mathrm{CI}=0.10$ to $0.34 ; \mathrm{p}<0.001)$.

There was an association between maternal BMI and obesity. Adolescents with obese BMI had a risk of obesity 3.15 
Journal of Epidemiology and Public Health (2019), 4(4): 328-337

https://doi.org/10.26911/jepublichealth.2019.04.04.08

times compared with BMI of mother who are not obese $(\mathrm{OR}=3.15 ; 95 \% \mathrm{CI}=1.74$ to $5.70 ; \mathrm{p}<0.001)$ and there was an association between paternal BMI and obesity.
Adolescents with obese paternal BMI had a risk for obesity 2.41 times compared with BMI of non-obese fathers (OR $=2.41 ; 95 \%$ $\mathrm{CI}=1.37$ to $4.25 ; \mathrm{p}=0.002)$.

Table 3 Results of multiple multilevel logistic regression

\begin{tabular}{|c|c|c|c|c|}
\hline \multirow{2}{*}{ Obesity } & \multirow{2}{*}{$\mathbf{O R}$} & \multicolumn{2}{|c|}{ 95\% CI } & \multirow{2}{*}{$\mathbf{p}$} \\
\hline & & Lower Limit & Upper Limit & \\
\hline \multicolumn{5}{|l|}{ Fixed Effect } \\
\hline Parental Income (High) & 4.53 & 1.80 & 11.36 & 0.001 \\
\hline Parental Knowledge (High) & 0.36 & 0.15 & 0.91 & 0.030 \\
\hline Pocket money (high) & 3.80 & 1.63 & 8.86 & 0.002 \\
\hline $\begin{array}{l}\text { Food intake ( } \geq \text { Recommended Dietary } \\
\text { Allowance (RDA) }\end{array}$ & 3.62 & 1.43 & 9.19 & 0.007 \\
\hline Physical Activity (high) & 0.06 & 0.02 & 0.18 & $<0.001$ \\
\hline Maternal BMI (obese) & 7.08 & 2.39 & 20.99 & $<0.001$ \\
\hline Paternal BMI (obese) & 2.63 & 1.10 & 6.32 & 0.031 \\
\hline \multicolumn{5}{|l|}{ Random Effect } \\
\hline \multicolumn{5}{|l|}{ School Food environment } \\
\hline Var (a constant) & 0.68 & & 0.08 & 5.92 \\
\hline $\mathrm{N}$ observation $=225$ & & & & \\
\hline Log likelihood $=-84.97$ & & & & \\
\hline LR test vs. linier regression, $p=0.014$ & & & & \\
\hline $\mathrm{ICC}=16.99 \%$ & & & & \\
\hline
\end{tabular}

\section{Multiple Logistics Multilevel Analysis}

Multivariate analysis explains the effect of more than one independent variable on one dependent variable. The method used was multilevel logistic regression using the Stata 13. program. Table 3 shows that there was an effect of parental income on obesity, this effect was statistically significant. Adolescent with high parental income, have a risk for obesity 4.80 times compared with low parental income $(\mathrm{OR}=4.53 ; 95 \% \mathrm{CI}=$ 1.80 to $11.36 ; p=0.001)$, there was an effect of parental knowledge on obesity, this effect was statistically significant. Adolescent with higher parental knowledge than low parental knowledge had a logodd for obesity $(\mathrm{OR}=0.36 ; 95 \% \mathrm{CI}=0.15$ to $0.91 ; \mathrm{p}=$ $0.030)$.

There was an effect of pocket money on obesity, this effect was statistically significant. Adolescent with high pocket money had higher logodd for obesity than those with low pocket money $(\mathrm{OR}=3.80$; $95 \%$
$\mathrm{CI}=1.63$ to $8.86 ; \mathrm{p}=0.002)$, there was an effect of food intake on obesity, this effect as statistically significant. Adolescents with food intake $\geq$ Recommended Dietary Allowance (RDA) rather than food intake $<$ Recommended Dietary Allowance (RDA) had logodd for obesity $(\mathrm{OR}=3.62 ; 95 \% \mathrm{CI}=1.43$ to 9.19; $\mathrm{p}=0.007$ ).

There was an effect of physical activity on obesity, this effect was statistically significant. Adolescent with high physical activity had a logodd to avoid obesity ( $\mathrm{OR}=$ 0.06; 95\% $\mathrm{CI}=0.02$ to $0.18 ; \mathrm{p}<0.001$ ), there was an effect of maternal BMI on obesity, this effect was statistically significant. Adolescents with obese maternal BMI have a logodd for obesity $(\mathrm{OR}=7.08$; $95 \% \mathrm{CI}=$ 2.39 to $20.99 ; \mathrm{p}<0.001)$ and there was an effect of paternal BMI on obesity, this effect was statistically significant. Adolescents with obese paternal BMI had a logodd for obesity $(\mathrm{OR}=2.63 ; 95 \% \mathrm{CI}=1.10$ to 6.32 ; $\mathrm{p}=0.031)$. 
Data analysis showed ICC results = $32.10 \%$. The indicator shows that $16.99 \%$ obesity variation was determined by variables at the school level. This figure is greater than the standard size of the role of thumb $8-10 \%$, so the contextual effect shown from multilevel analysis was very important to note. The table shows $\mathrm{p}=$ 0.014, meaning that the multilevel model is statistically significantly different from the ordinary linear regression model.

\section{DISCUSSION \\ 1. Effects of parental income on ado- lescent obesity}

The results of this study indicate there is an effect of parental income on adolescent obesity; the results of this study are in accordance with the explanation of Marlissa et al. (2015) which stated that parental income is one of the determinants of adolescent obesity. Parents who have high incomes have greater opportunities in choosing the type of food, these opportunities lead to the choice of types and quantities of food no longer based on needs and health considerations, but rather leads to practical considerations, such as fast food. Parengkuan et al. (2013) also explained that parental income affect adolescent obesity.

\section{Effect of parental knowledge on adolescent obesity}

The results of this study indicate there is an effect of parental knowledge on adolescent obesity. Parental knowledge increases the risk of adolescent obesity which is statistically significant. Knowledge is one of the determinants of factors affecting adolescent obesity.

Liu et al. (2016) stated that the knowledge of parents, especially mothers in determining the type of food is needed by the family, high parental knowledge is useful to give parents ease in choosing food ingredients that are in accordance with the nutritional needs of the family so that food intake can be controlled so that it can reduce risk of obesity. Manios et al. (2014) also explained that the risk of obesity in children aged 10-12 years was decreased due to high parental knowledge.

\section{Effect of pocket money on adoles- cent obesity}

The results of this study indicate there is an effect of pocket money on adolescent obesity, an allowance to increase the risk of adolescent obesity which is statistically significant. Pocket money can affect food purchases and adolescent body weight. Provision of pocket money by parents, can give adolescent the freedom to make choices in buying and consuming snacks at school ( $\mathrm{Li}$ et al., 2017).

Punitha et al. (2014) explained that another goal in giving high allowances to adolescents was the hope to instill savings habits, but a popular newspaper in India stated that, the trend of pocket money increased and a lot of expenditure was used to buy food.

\section{Effects of food intake on adoles- cent obesity}

The results of this study indicate that there is a significant effect between food intake on adolescent obesity. Obesity is a public health problem that needs attention. Energy imbalances caused by living conditions and exercise habits, result in obesity with excessive energy accumulation (Park and Jung, 2016). Almasith et al. (2018) explain that obesity can also reduce quality of life.

Poor eating habits and lack of physical activity are factors that play a role in the occurrence of obesity in adolescents, in addition to the results of the study also showed that the habit of not eating breakfast is associated with the risk of obesity in adolescents so further studies are needed to identify the level and effectiveness of healthy dietary education in adolescents to 
prevent an increase in the prevalence of obesity (Eker et al., 2018).

Susanti et al. (2016) explained that excess food intake has a risk of 3.31 times the occurrence of obesity compared with less food intake Lazzeri et al. (2014) also showed that low breakfast habits increase the risk of obesity.

\section{Effects of physical activity on ado- lescent obesity}

The results showed there was a significant effect on physical activity on adolescent obesity. Adolescent with high physical activity are more likely to reduce the risk of adolescent obesity. Low physical activity is one of the key factors affecting adolescent obesity. Eker et al. (2018) explained that the effort to reduce the incidence of obesity in adolescents is to increase the learning of physical activity through sports activities in more schools.

Adolescent who lack activity will experience a decrease in basal metabolism so that the body stores calories and causes fat accumulation resulting in obesity, thus physical activity is very important for weight loss and regulation of basal metabolism (Fernández-Alvira et al., 2013).

\section{Effects of maternal BMI on adoles- cent obesity}

The results of this study indicate there is an effect of maternal BMI on adolescent obesity, maternal BMI increases the risk of adolescent obesity which is statistically significant. Obesity has been dissociated with various risk factors including genetics, lifestyle and certain diseases. Obesity is affected by genetic factors which are passed on to their offspring. Obese parents are determinants of obesity during childhood and adolescence. Maternal adipocyte is one predictor of childhood obesity (Shafaghi et al., 2014).

The correlation of maternal BMI with boys is significant at the age of 5-6 years, continuing through puberty and early adulthood which is 18 years. The correlation of maternal BMI with girls is significant at the age of 1.5 years, continuing through adolescence, puberty and early adulthood which is 18 years (Swanton et al., 2017).

\section{Effects of paternal BMI on adoles- cent obesity}

The results of this study indicate there is an effect of paternal BMI on adolescent obesity, paternal BMI increases the risk of adolescent obesity which is statistically significant. Bahreynian et al. (2017) shows that obesity in older people affects adolescent obesity.

Body mass index (BMI) in children, not only seen from the history of maternal BMI, but also the BMI of the father. Epidemiological study data show that food and paternal health conditions can program the next generation. So, mothers are not the only genetic factors that affect adolescent health (Ornellas et al., 2017). The results of the study show that children with a BMI of obese fathers have a risk of 2.02 times the occurrence of obesity compared to children with a normal paternal's BMI (Shafaghi et al., 2014).

\section{Effects of school food environment on adolescent obesity}

The results of the study with multilevel analysis showed that ICC $=16.99 \%$. The indicator shows that the environmental conditions of school food environment in each stratum have an environmental effect on adolescent obesity variations of $16.99 \%$. Hence, the environmental effect of the school shown from multilevel analysis is very important to consider.

Ahmad et al. (2017) explained that environmental factors are factors that affect the incidence of adolescent obesity. This is in line with Widiyanto et al. (2018) which showed that the school environment has an 
ICC $=9.92 \%$. Shafaghi et al. (2014) also explained that the environment is a determining factor for obesity.

A study conducted in Semarang found that there was a significant association between western fast food and local snacks with adolescent obesity. Snack food is defined as local food that is traded in the school environment (Pranomo and Sulchan, 2013).

Based on the results of the study it can be concluded that there is an effect of high parental salary, low parental knowledge, high pocket money, food intake $\geq$ nutritional needs, physical activity, obese maternal BMI and obese paternal 's BMI in increasing the incidence of obesity in adolescent. Variations at the school level show contextual effects on obesity.

\section{AUTHOR CONTRIBUTION}

Rita Setiyaningsih collected and analyzed data. Yulia Lanti Retno Dewi examined the conceptual framework and methodology of the study. Rita Benya Adriani provided input on the instruments of the study used.

\section{CONFLICTS OF INTEREST}

No conflicts of interest.

\section{FUNDING AND SPONSORSHIP}

This study used independent funding from the main researcher.

\section{ACKNOWLEDGEMENT}

We thank the school for helping us in conducting this study and the students who participated to become participants.

\section{REFERENCES}

Ahmad A, Zulaily N, Shahril MR, Abdullah EFH, Ahmed A (2018). Association between socioeconomic status and obesity among 12-year-old Malaysian adolescents. PLoS ONE, 13(7): eo20-
0577. Doi: https://doi.org/10.1371/journal.pone.0200577.

Almasith YK, Dewi YLR, Wekadigunawan CSP. (2018). Path Analysis on the psychosocial impact of obesity or overweight in adolescents in Surakarta, Central Java. Journal of Epidemiology and Public Health, 3(2): 105-117. Doi: https://doi.org/10.26911/jepublicheal th.2018.03.02.01.

Bahreynian M, Qorbani M, Khaniabadi BM, Motlagh ME, Safari O, Asayesh H, Kelishadi R (2017). Association between obesity and parental weight status in children and adolescents. J Clin Res Pediatr Endocrinol, 9(2):111-117. DOI: $10.4274 /$ jcrpe.3790.

Eker HH, Taşdemir M, Mercan S, Mucaz M, Bektemur G, Şahinoz S, Özkaya E (2018). Obesity in adolescents and the risk factors. Turk J Phys Med Rehab, 64(1):37-45. DOI: 10.5606/tftrd.2018.1402 .

Fernández-Alvira JM, Velde SJ, Bourdeaudhuij ID, Bere E, Manios Y, Kovacs E, Jan N, Brug J, Moreno LA (2013). Parental education associations with children's body composition: mediation effects of energy balance-related behaviors within the energy-project. Int J Behav Nutr Phys Act, 10:80. Doi: http://www.ijbnpa.org/content/10/$1 / 80$.

Kelsey MM, Zaepfel A, Bjornstad P, Nadeau KJ (2014). Age related consequences of childhood obesity. Gerontology, 60: 222-228. DOI: 10.1159/o00356023.

Lazzeri G, Giacchi VM, Spinelli A, Pammolli A, Dalmasso P, Nardone P, Lamberti A, et al. (2014). Overweight among students aged 11-15 years and its relationship with breakfast, area of residence and parents' education: Results from the Italian. Nutrition Journal, 
Journal of Epidemiology and Public Health (2019), 4(4): 328-337

https://doi.org/10.26911/jepublichealth.2019.04.04.08

13:69. Retrieved from http://www.nutritionj.com/content/13/1/69.

Li M, Xue H, Jia P, Zhao Y, Wang Z, Xu F, Wang Y (2017). Pocket money, eating behaviors, and weight status among chinese children: the childhood obesity study in China megacities. Preventive Medicine, 100: 208-215. Doi: http//dx.doi.org/10.1016j.ypmed.2017.04.031.

Liu S, Hu SH, Wang YV, Qiu JM, Melkus GD (2016). Accuracy of body weight perception and obesity among Chinese Americans. Obes Res Clin Pract, 10(1): S48-S56. DOI:10.1016/j.orcp.2015.04.004.

Manios Y, Androutsos O, Katsarou C, Iotova V, Socha P, Geyer C (2014). Designing and implementing a kindergarten-based, family-involved intervention to prevent obesity in early childhood: the toybox-study. Obesity Reviews, 15: 5-13. DOI: 10.1111/obr.12175 .

Marlissa EW (2015). Perilaku orang tua dan keluarga terhadap obesitas pada anak kelas 5 sd di SDN 70 Manado. JKKT. 3: 229-234. Retrieved from https://ejournal.unsrat.ac.id/index.php/JK KT/article/view/11263.

Ornellas F, Carapeto PV, De Lacerda CAM, Aguila MB (2017). Obese fathers lead to an altered metabolism and obesity in their children in adulthood: Review of experimental and human studies. $J$ Pediatr (Rio J). 93: 551-559. DOI: http://dx.doi.org/10.1016/j.jped.2017 .02.004.

Parengkuan RR, Mayulu N, Ponidjan T (2013). Hubungan pendapatan keluarga dengan kejadian obesitas pada anak sekolah dasar di Kota Manado. Jurnal Keperawatan, 1: 1-7. Retrieved from https://ejournal.unsrat.ac.id/index/php/jkp/articleview/2227.
Park JW, Jung DI (2016). Integumentary physical therapy. Berlin: Springer.

Pramono A, Sulchan M (2014). Kontribusi makanan jajan dan aktivitas fisik terhadap kejadian obesitas pada remaja di Kota Semarang. Gizi Indon, 27: 129-136. Retrieved from http://id.portalgaruda.org/?ref=browse\&mod+viewarticle\&article $=322238$.

Punitha VC, Amudhan A, Sivaprakasam P, Rathnaprabhu V (2014). Pocket money: influence on body mass index and dental caries among urban adolescents. J Clin and Diagn Res, 8: JC10-JC12. Doi: 10.7860/JCDR/2014/10498.

Riset Kesehatan Dasar (2013). Kecenderungan Prevalensi Obesitas Sentral Penduduk Umur $\geq 15$ tahun, Menurut Provinsi, Indonesia 2007 dan 2013. Retrieved from http://www.depkes.go.id/resources/download/general/H asil\%20Riskesdas\%202013.pdf.

Shafaghi K, Shariff ZM, Nasir M, Taib M, Rahman HA, Mobarhan MG, Jabbari $\mathrm{H}$ (2014). Parental body mass index is associated with adolescent overweight and obesity in Mashhad, Iran. Asia Pac J Clin Nutr. 23: 225-231. DOI: 10.6133/apjen.2014.23.2.11.

Susanti RPF, Murti B, Indarto D (2016). Maternal employment status, ethnicity, food intake, and their effects on teenage obesity, in Surakarta. Journal of Epidemiology and Public Health, 1(2): 75-85. Doi: https://doi.org/10.26911/jepublichealth.2016.01.02.01

Swanton S, Choh AC, Lee M, Laubach LL, Linderman JK, Czerwinski SA, Peterson MJ (2017). Body mass index associations between mother and offspring from birth to age 18: the fels longitudinal study. Obes Sci Pract. 3: 127-133. Doi: 10.1002/osp4.90. 
Widiyanto A, Murti B, Soemanto RB (2018). Multilevel analysis on the effects of socio-cultural, lifestyle factors, and school environment, on the risk of overweight in adolescents, Karanganyar District, Central Java. Journal of Epidemiology and Public
Health, 3(1): 94-104. Doi: https://doi.org/10.26911/jepublichealth.2018 .03.01.08.

World Health Organization (2018). Obesity and overweight. Retrieved from http://www.who.int/en/news-room/factsheets/detail/obesity-and-overweight 